\title{
LA LÍRICA SANTIAGUERA EN LA ETAPA REPUBLICANA (1923-1958): POSMODERNISMO, VANGUARDISMO Y NEORROMANTICISMO ${ }^{1}$
}

\author{
Ronald Antonio Ramirez-Castellanos ${ }^{2}$ \\ Universidad de La Habana, Cuba
}

\begin{abstract}
Resumen: Este artículo complementa el estudio de la lírica santiaguera en la etapa republicana (1923-1958), donde convergen las estéticas posmodernistas, vanguardistas y neorrománticas en el espectro literario y cultural de la ciudad. La investigación ofrece zonas de interés a las actuales investigaciones de instituciones académicas y culturales vinculadas al proceso de rescate del patrimonio literario y cultural de Santiago de Cuba. Se trata de una literatura preterida y desconocida por la historiografía literaria cubana. La revisión de fuentes hemerográficas, textos poéticos del período y la aplicación del análisis de contenido como método general permitieron dilucidar los autores, obras y sus diferentes manifestaciones ideoestéticas del género poético, cuyas aportaciones resultan medulares para el necesario ejercicio de reescritura de la historia literaria regional.
\end{abstract}

Palabras clave: Autores; etapa republicana; lírica; obras; Santiago de Cuba.

Recibido: 06 diciembre de 2018

Aprobado: 18 febrero de 2019

\section{LYRIC FROM SANTIAGO DE CUBA IN THE REPUBLICAN PERIOD (1923-1958): POSTMODERNISM, AVANT-GARDE AND NEO-ROMANTICISM}

Abstract: The study of the lyric in Santiago de Cuba in the Republican stage offers areas of interests to current research being conducted in academic and cultural institutions in the territory, as it is known the vast poetic tradition that this region has consolidated over

\footnotetext{
${ }^{1}$ Este artículo es resultado de investigación del Proyecto "Gestión y conservación del patrimonio literario de Santiago de Cuba (siglos XIX, XX y XXI)”, de la Universidad de Oriente, Santiago de Cuba, en colaboración con la Universidad de La Habana, Ministerio de Educación Superior de la República de Cuba.

${ }^{2}$ Actualmente imparte docencia en el Departamento de Estudios Lingüísticos y Culturales de la Fenhi, Universidad de La Habana, donde imparte docencia de Literatura Cubana e Hispánica. En la Universidad de Oriente, dictó clases de latín, griego y Literatura Cubana. Ha realizado investigaciones sobre el patrimonio literario e historiográfico de Santiago de Cuba. Correo electrónico: ronaldinhosoyyo@gmail.com
} 
the years. From the flowering of avant-garde aesthetic, a qualitative leap is evident in the publication of poems, now unknown to the national literary historiography. That is why, in this paper, aspects of interest which can identify the authors, texts and different ideosthetics manifestations of the poetic genre whose contributions are core to the necessary exercise in rewriting of literary from Santiago de Cuba were disentangled between 1923-1958.

Keywords: Authors; lyric; Republican stage; Santiago de Cuba; texts.

\section{Introducción}

En un estudio anterior quedaron definidas las particularidades de la exégesis poética en el panorama literario y cultural de la ciudad de Santiago de Cuba en la etapa republicana comprendida entre 1902 y 1923 (Ramírez 201-220). La investigación demostraba, a partir de un análisis de las principales vertientes temáticas de la poesía en esa región, sus autores y obras más representativas; un corpus poético nutrido, por lo regular, de la savia romántica del período colonial del siglo XIX cubano, cuyos aportes, desde la literatura, fueron notables para el paulatino proceso de gestación de la identidad nacional y la patrilocalidad santiaguera. Las motivaciones esenciales partían de la necesidad de estudiar una práctica escritural relegada por los estudios relacionados con la historiografía y la ciencia literaria en Cuba, dado el enfoque habanocentrista, típico de los manuales, compendios e historias de las literaturas en el país, desde su gestación hasta la etapa contemporánea.

Era preciso destacar que la ciudad de Santiago de Cuba había sido, desde el siglo XIX hasta hoy día, una plaza cultural importante en la cual la literatura encontró un potencial menospreciado por las investigaciones relacionadas con la temática. El tránsito a la era republicana, sobre todo, contribuyó de modo fehaciente a fortalecer la fisonomía lírica de la región, así como otros géneros literarios que merecen un detenimiento exhaustivo en los estudios culturales de y sobre la ciudad, sus prácticas literarias y actores culturales predominantes, con el propósito de contribuir a la conformación de una historia de la literatura local todavía inexistente. 
El presente estudio tiene como objetivo fundamental dar continuidad a esa investigación anterior, particularizando el acercamiento a las estéticas del hecho poético en Santiago de Cuba en el período 19231958. Este lapso cronológico responde a los siguientes criterios de metodología:

1) Complementar el estudio del hecho poético en Santiago de Cuba durante la etapa republicana burguesa (1902-1958), años que enmarcan el fin de la dominación colonial española y la intervención norteamericana en la isla con la fundación de la República el 20 de mayo; así como la caída de la dictadura de Fulgencio Batista con el advenimiento al poder de la revolución de Fidel Castro, respectivamente. Estos acontecimientos sociopolíticos se asumen como límites cronológicos para el estudio de la literatura nacional en el campo de la historiografía y las ciencias literarias cubanas (Instituto 273-438) y de este modo resultan direccionalmente aplicables a los procesos culturales y literarios regionales en el país. 2) En el artículo citado (Ramírez 201220) el análisis de la lírica santiaguera en una primera etapa (1902-1923) determinó las pautas que definieron la exégesis del hecho poético y sus movimientos estéticos predominantes: el romanticismo con rezagos de la tradición colonial al uso, el posmodernismo o modernismo tardío y la antesala al movimiento vanguardista, con sus autores y obras primordiales. En la presente investigación se toma en cuenta el período posterior, que enmarca la decadencia del movimiento posmodernista (1923-1926), la entronización de las vanguardias literarias con extendida incidencia en la literatura regional (1926-1937) y el asentamiento de la estética neorromántica hasta su fase epigonal (1937-1958).

Este artículo valora las obras más importantes de autores nacidos en esta ciudad que no solo desarrollaron su quehacer lírico en los círculos intelectuales de la región sino también los santiagueros que, en un período posterior, luego de participar en el ambiente cultural de la ciudad, residieron en otros lugares de la isla. También considera los no nativos (nacionales o foráneos) que convivieron de manera permanente -por lo regular, los más escasos-, integrados a la vida literaria de la urbe como parte de un núcleo intelectual diaspórico con una contribución decisiva a la cultura local, criterio válido y por lo general menospreciado en la actualidad. 
La metodología cualitativa empleada asume el análisis de contenido de dichas obras y la observación del continuum lírico desde una perspectiva historiográfica, con el propósito de establecer un mapa de referancia de su evolución ideoestética en el contexto cultural santiaguero; por el contrario, un análisis estético al interior de cada una de las obras y autores aquí analizados de manera casuística escaparían a los límites de esta investigación. La estrategia discursiva del análisis sigue las pautas de un ordenamiento cronológico, siempre que sea posible, lo cual transparenta las particularidades de los tres movimientos estéticos fundamentales en el género lírico del período: el postmodernismo, ${ }^{3}$ la vanguardia y el neo-romanticismo.

Al privilegiar el enfoque historiográfico literario, esta investigación aporta una comprensión pionera del hecho poético en la región. Determinar su legado para la historia de la literatura cubana en general y santiaguera en particular, constituye otro aporte de esta investigación para las ciencias literarias en Cuba y sus estudios académicos regionales y culturales. Del mismo modo, contribuye al rescate del patrimonio literario de la ciudad de Santiago de Cuba, hasta el presente preterido, invisibilizado, y responde a la necesidad de preservar la memoria histórica del pasado patrilocal y de la nación cubana, así como su validación dentro del contexto de las historias literarias locales en el ámbito latinoamericano.

\section{Posmodernismo y romanticismo epigonal: maridaje y decadencia de un continuum lírico}

La efervescencia cultural que experimenta la ciudad de Santiago de Cuba a partir de los años veinte del pasado siglo tuvo en la literatura una significación importante, sobre todo para el desarrollo

\footnotetext{
${ }^{3}$ Se asume, como en el trabajo que anteriormente inicia este estudio (Ramírez 206: 201-220) el criterio asentado por la crítica y la historiografía literarias cubanas de denominar "postmodernismo" o "modernismo tardío" a la nueva estética lírica surgida en Cuba a partir de 1913 con la publicación de Arabescos mentales del poeta Regino E. Botti (1886-1958). Como se ha definido, esta denominación no es otra que el denominado modernismo abanderado por las poéticas de Julián del Casal y José Martí, truncas a finales del siglo XIX con la muerte prematura de ambos autores, y solo después retomadas tardíamente por los autores santiagueros integrantes de la conocida Generación del Palo Hueco, cuyo líder fue el poeta local José Manuel Poveda. Es preciso aclarar que el término no tiene relación con el concepto "posmodernismo" que designa por lo regular las tendencias culturales actuales en el arte, la literatura y el contexto sociopolítico de finales del siglo XX e inicios del XXI de las sociedades contemporáneas.
} 
del género lírico que hereda los preceptos formales y conceptuales de las prácticas poéticas sedimentadas en las décadas fundacionales de la era republicana en el país. Estas estéticas se concentran en dos directrices fundamentales: la primera, la exégesis romántica del período finisecular del XIX que predominó hasta 1912, en la que conviven expresiones de una poesía patriótica, en muchos casos evocadora de un pasado histórico reciente: el de las luchas por la emancipación nacional y la exaltación del legado de los próceres de la insurgencia (la figura de Antonio Maceo, en primer lugar, y luego la de José Martí), con el propósito de contrarrestar el sentimiento de frustración, el pesimismo y la enajenación política que experimentó la intelectualidad santiaguera, a tono con el difícil contexto sociopolítico del país.

La segunda fue, precisamente, lo que la historiografía literaria cubana denominó postmodernismo, cuyo manifiesto, gestado en Santiago de Cuba, vio la luz en el suplemento literario "Los Domingos de El Cubano Libre" en 1914. El afán renovador se alzó contra la prevalencia de un romanticismo epigonal que escasamente aportaba al hecho lírico insular; un movimiento literario surgido en la entonces provincia de Oriente con la publicación, en la ciudad de Guantánamo, de Arabescos mentales (1913) de Regino Eladio Botti y en Santiago, de Versos precursores (1917) de José Manuel Poveda (1888-1926). ${ }^{4}$ Como ya se ha señalado (Ramírez 2016), la impronta del parnasianismo francés, el legado del poeta nicaragüense Rubén Darío y del cubano José Martí, fueron asimilados por autores, además de Poveda, como Fernando Torralva (1885-1913), Luis Vázquez de Cuberos (1889-1922), el colombiano Pascual Guerrero (1894-1946), residente en la ciudad por esos años, Juan Francisco Sariol (1888-1968), entre otros, cuyas primeras publicaciones poéticas aparecieron en las revistas culturales Ilustración Cubana (1906), Renacimiento (1909-1910), Oriente

\footnotetext{
${ }^{4}$ Como en el estudio anterior, en este artículo se identifican solo para los autores santiagueros las fechas de nacimiento y muerte. Sin embargo, por tratarse de autores por lo regular desconocidos, no siempre puede contarse con la precisión de este dato porque no se cuenta con materiales bio-bibliográficos en los archivos bibliotecarios de la ciudad y el país que lo indiquen. Las aquí incluidas se toman de las referencias fundamentales (Instituto; Estrada) y de las revisiones a las fuentes hemerográficas principales de la ciudad de Santiago de Cuba en el período republicano que pudieron aportar estos indicios. Cuando no es posible ofrecer uno de ellos o ambos, se incluirá un signo de interrogación o aparecerán sus nombres sin las indicaciones respectivas de los años de nacimiento y muerte, como tradicionalmente se estipula para estos casos.
} 
Literario (1910-1913) y en el suplemento cultural de El Cubano Libre, así como en poemarios que compilaron la producción poética en estos años, generalmente centrados en esa estética literaria. De los escritores mencionados, lamentablemente solo Poveda alcanzó el reconocimiento por la historiografía literaria cubana, debido a sus indiscutibles aportes al género lírico cubano en ese lapso.

Es importante subrayar que esta segunda tendencia estética, aunque pretendió una supremacía en el hecho lírico regional e insular, encontró una fuerte oposición en quienes continuaban escribiendo a la usanza romántica del siglo XIX. A pesar de las polémicas culturales y los encontronazos que posmodernistas y románticos protagonizaron en las páginas literarias de El Cubano Libre, uno y otro bando convergieron, al menos, hasta mediados de la década de los años veinte. Ya en 1923, el panorama poético santiaguero lejos está de mostrar una variación conceptual y temática pues los poemarios publicados desde esa fecha, aunque de apreciables registros ideoestéticos, discurren entre el tradicionalismo y la estéril renovación sin el predominio preponderante de alguna de estas tendencias. El propio posmodernismo, tras el silencio de Poveda -que solo publicó un poemario- y su posterior fallecimiento prematuro en 1926, prácticamente ya no tenía nada que aportar. No obstante, merecen mencionarse algunos títulos que sobresalen en la peculiar producción poética de autores santiagueros durante la década.

Los énfasis antiguos (1924), de Rafael Esténger Neuling (18991983), intelectual y antologador del género en Cuba con significativos aportes ensayísticos y compilaciones sobre la lírica insular en el período republicano, asienta su preferencia por la exégesis postmodernista al revelar una actitud filosófica desesperanzadora y nihilista, en composiciones como "El tríptico de las ansias", "Poemitas de breviario", "Consuetudinaria" y "Yo pecador", por solo citar algunos, en los cuales el hablante lírico transparenta su frustración ante la incapacidad de transformar como individuo el asfixiante entorno sociopolítico que condicionaba la actitud pesimista de los escritores de la primera generación republicana. Aun cuando la práctica del soneto está presente en determinados textos del poemario, es posible advertir un denodado prosaísmo lírico cercano al tono conversacional, estética que signa el 
preludio del cambio que algunos autores locales desplegarán a finales de esta década.

Por otro lado, Arturo Clavijo Tisseur (1886-1958), que había iniciado su carrera poética en 1917 con Albores y penumbras y más tarde con su segundo volumen Consagración eterna. Poesías y prosas (1922), edita su texto Cantos a Elvira (1925), muy celebrado por la crítica nacional y extranjera. El poemario lo consagra como el poeta más popular de la entonces provincia cubana de Oriente (Villaespesa 3) y no esconde la influencia neorromántica de la poesía hispanoamericana de la época, en particular la de Amado Nervo, aunque con moderados coqueteos postmodernistas que alientan los temas relacionados con el amor místico y la constante búsqueda de la espiritualidad del yo poético, como contrapartida al ambiente belicista del nuevo siglo con el estallido de la devastadora Gran Guerra en Europa en 1914. Es esta la marca ideoestética recurrente en composiciones esporádicas de Clavijo Tisseur, presentes incluso desde su primer libro Albores y penumbras. Como nota distintiva, en Cantos a Elvira aparecen alusiones a los temas de la mitología grecolatina en los sonetos "El rapto de Europa", "La prisión de Juno", "Diana o Febea" y "El reino de Plutón”, así como la preocupación del sujeto lírico por la trascendencia de su obra en "El poeta aclama la gloria" y "El retorno", ambos poemas incluidos en este volumen.

En ese mismo año, el santiaguero Manuel Bisbé y Alberni (19061961), radicado ya en La Habana, entrega su libro En los jardines del silencio (1925), místico y simbólico en sus inquietudes filosóficas, que advierten la denodada obsesión, el desconcierto y la incomprensión del hombre ante los misterios de la vida y la muerte. Se trata de una poética escrita en sus años juveniles, en la cual asoma la actitud desesperanzada del hablante lírico, la dicotómica tensión entre la razón y la pasión, la luz y la oscuridad, el aislamiento y la búsqueda denodada de la espiritualidad trascendente que aliena al hombre de las complejas realidades de la vida, considerada mundana y pueril; temas muy similares a los abordados por Pascual Guerrero en su poemario Voces del silencio (1915). El silencio, la noche, la contemplación y el olvido en "Federico Nietzsche", "La canción de la Esfinge", "El misterio inviolable de algún mito" o en las 
composiciones sin título que inician el poemario de Bisbé, urden un condensado intimismo lírico que pondera el hastío y el ostracismo del yo, sumergido en sus esencias metafísicas en el decurso de un tiempo sin presente en el que solo existe el pasado y una mirada hacia el futuro llena de incertidumbre, escepticismo y miedo ante lo desconocido.

Pedro Duany Méndez (1891-1952), quien regularmente signaba sus publicaciones en la prensa de la época con su seudónimo Saulo de Tarso, publica Hipocrene. Versos emotivos (1926), texto que combina la ejecutoria de lo renovador y el esteticismo romántico tradicional, en esencia, espiritualista y de armonía sensibilizadora. "Pienso en ti", "Alma trágica", "Tragedia" y "La huérfana" son poemas que insisten en la proyección quejumbrosa del hablante lírico ante el agobio, en el suicidio como paliativo al dolor que ocasiona el fracaso amoroso y la ausencia de la mujer amada. Saulo de Tarso emula la exégesis de un tardío modernismo con signos lapidarios de agonía y, a veces, una poesía que pretende más de lo que realmente consigue en su contenido temático y hechura composicional. En cierta medida, todo el poemario se resiente por su lirismo intrascendente y poco elaborado. Llama la atención, además, la presencia de poemas apegados a la vertiente patriótico-histórica en los que se aprecia, más que la exaltación al legado de los próceres, el compromiso con una política desacertada, aduladora y francamente insustancial.

El escritor español radicado en Santiago, Joaquín Aristigueta Sanromán, quien ya venía entregando algunas publicaciones poéticas aisladas en el suplemento literario de El Cubano Libre, entrega su libro Huerto escondido (1926), en tanto que también, en ese año, Manuel Siré Valenciano edita Del plantel al mesón, semblanzas líricas. Figuras del plantel. Entre escudillas. Figuras del mesón (con prólogo de Armando R. Maribona), y Luis Augusto Méndez publica Trémulos y pétalos, poemarios de escaso vuelo artístico.

A diferencia de los anteriores, Crepúsculos fantásticos (1927), de Héctor Poveda Sánchez (1890-1968), resulta lo más interesante publicado por autores santiagueros en el contexto de la decadencia posmodernista en la lírica a fines de esta década. En su libro, Héctor Poveda reúne varias composiciones escritas en su mayoría entre 1915 
y 1921. La evocación de experiencias personales de vida en el pasado, la imagen nostálgica de una compañía ausente ("Solo de bohemios"), la musicalidad del verso pausado, cerebral, matizado por un lenguaje rebuscado, tendiente a la arquitectura de la metáfora críptica y en no pocas ocasiones, también, antitética ("Nocturno", "Los paisajes neuróticos" y "Noche actual de Walpurgis"), evidencian la clara influencia de la estética de Versos precursores de su primo José Manuel Poveda. En Crepúsculos... el misticismo orienta la retórica del discurso poético; el ambiente recurre a paisajes lúgubres, como la nocturnidad de un camposanto o la mustia naturaleza del contexto provinciano. El amor como tema en sus composiciones orienta la apoteosis filosófica de un sujeto lírico desorientado ante los avatares de un destino incierto. La noche será, por tanto, el refugio predilecto para el despliegue de su neurosis-psicosis. Poética del desencanto, Crepúsculos fantásticos, en síntesis, transparenta el rictus amargo del yo autoral, su faz abúlica y desnortada como símbolo de la decadencia de una etapa de pauperismo cultural y de infortunio, que anhela con insistencia casi demencial encontrar la ruta para una vida más llevadera.

Canto a la raza (1928), extenso poema épico de trasfondo histórico, de Fernando García Grave de Peralta (1876-1963), y Antología ideal (1928), de Clavijo Tisseur, este último de heterogénea composición, sistemático en los modos, formas y temas abordados en los títulos anteriores del autor, complementan la lista de los publicados al final de la década. Todavía en este año el poeta más popular de Oriente tendrá por encargo la responsabilidad de dotar a Santiago de Cuba de su himno patriótico, aprobado por el Ayuntamiento local y asumido finalmente como canto oficial de la ciudad el 1 de enero de 1929.

Como colofón a las particularidades del hecho lírico regional que distingue a este lapso, es importante hacer referencia a las estéticas y temáticas que centrarán, fundamentalmente, los temas de la poesía santiaguera de autoría femenina. La devoción religiosa, los roles asignados a la mujer en el espacio doméstico, la consagración al matrimonio y a la maternidad, la correspondencia o el desengaño amorosos, la ironía sentimental o el dolor ante la pérdida del hijo amado, serán los tópicos constantes tratados por Caridad Tintoré 
(1882-?), Dolores Elvira Valbuena de Moro (1851-?), Enriqueta Parladé, Evangelina Pujadas, Elvira Castillo (1886-?) y otras poetas que mantendrán una eventual presencia en las publicaciones culturales de estos años. De ellas, además de Caridad Tintoré -publicó en 1907 su libro Ensayos poéticos-, solo Elvira, primera esposa de Clavijo Tisseur, conseguirá editar un volumen de versos, Crisálidas (1931), de irrelevante calidad estética. De mayor atención para el estudio de la lírica femenina de la etapa, se advierten los textos de la pinareña Ciana Valdés Roig (1895-?), residente en Santiago de Cuba y más tarde en Guantánamo, así como los poemas sueltos, todavía no compilados en libro, de Mariana de la Torre (1895-?) y Mariblanca Sabas Alomá (1901-1983), autoras más cercanas al discurso de la modernidad, por lo regular transgresoras en el tratamiento de problemáticas diversas como las reivindicaciones morales de la mujer y los polémicos tópicos vinculados al erotismo y la sexualidad femeninas. En el caso de Sabas Alomá, resulta notable la existencia de una prolífera labor poética en publicaciones periódicas y culturales del período, tanto de Santiago de Cuba como en La Habana, ciudad donde residirá finalmente a partir de la tercera década del siglo XX y desarrollará una carrera política y proselitista en favor de la emancipación social y el reconocimiento de los derechos de la mujer. Hasta donde ha sido posible revisar, la poesía de Mariblanca Sabas Alomá ve la luz primeramente en la "Sabatina Literaria" de El Cubano Libre en 1919, posteriormente en las revistas Actualidades (1920) y Luz de Oriente (1922-1924), en el periódico Diario de Cuba, todos de Santiago de Cuba, y luego en Social y Carteles de La Habana, hasta finales de los años cincuenta. Lamentablemente, hasta el presente, esta obra poética todavía dispersa, no se ha contabilizado en su totalidad ni estudiado sus aportes a la literatura cubana de estos años.

\section{Las estéticas líricas vanguardistas: el frustrado soplo revitalizador}

La aparición de dos grupos literarios de tendencias renovadoras evidencia "el reflejo de las vanguardias" (López Lemus 59) en la lírica santiaguera republicana. El primero, autotitulado Per se, surge el 6 de mayo de 1926 y tuvo como órgano difusor una página literaria semanal 
en el periódico local La Independencia, que acogió las firmas más reconocidas del espectro cultural citadino: los hermanos Manuel (19011990) y Francisco Palacios Estrada, Julián Mateo (1906[1907?]-1942), Gastón B. Hernández (1866-?), Daniel Bertrán Maroto (1869-?), Arturo Clavijo Tisseur, Saulo de Tarso, Lino Horruitiner (1902-1972), Pedro Calderón y Luis Aguiar Poveda (1899-1976?); este último, responsable de la proyección ideoestética de los "perseístas" y de su afán renovador.

El surgimiento de este grupo, a los efectos de un estudio cronológico y de periodización de la lírica santiaguera en el período, ocurre justo en el año del fallecimiento de José Manuel Poveda, abanderado de la renovación posmodernista en el país. Si bien la exégesis poética povedeana significó una ruptura conceptual con los trillados moldes románticos de la lírica decimonona cubana que autores locales intentaron estigmatizar durante los primeros años republicanos, los "perseístas" representaron un intento de orientación formal y conceptual de la poesía, ajeno a los propósitos ahora caducos de la práctica lírica posmoderna. Las pretensiones de emular la actividad literaria de grupos nacionales y extranjeros con similares propósitos transformadores -por ejemplo, el Grupo de Manzanillo en la región oriental del país y el Minorista de La Habana, además del foráneo Paladión de Santo Domingo en República Dominicana-, auguraban una revitalización de la actividad literaria en la capital oriental del país.

Sin embargo, el saldo productivo no evidenció una significativa recepción de las tendencias vanguardistas europeas en Santiago de Cuba, a diferencia de los poetas habaneros, estos con una participación intelectual mucho más activa debido a sus frecuentes contactos con la cultura y la literatura del Viejo continente. Particularmente en la lírica, no se publicó en la página del Grupo Per se, salvo algunos balbuceos poéticos de Julián Mateo adscritos a esta nueva corriente ("Vida buena y sencilla", "Nirvana simbólico" y "El cuadro de mi cuarto"), nada que no estuviera dentro de los códigos escriturales posmodernistas y neorrománticos manidos. Daniel Bertrán Maroto, Pierrot, más conocido por sus composiciones de trasnochada cursilería, sobresale entre los más publicados con "Yo quisiera", “iSalve, oh Reina!", "Capricho", "Versos fin de siglo", "La serenata", "Contestando a Colombina", "Altivez" y 
“A la señorita Cuba Torres". Enrique Cazade Palacios mantiene la línea sensiblera de su anterior libro Cantos de amor y de olvido (1920) con su poema "Ambigua"; Arturo Clavijo Tisseur alaba la impronta de un poeta español que dejó su huella en la ciudad en "Alfonso Camín", y publica luego "La ofrenda"; emulado por Saulo de Tarso ("Alfonso Camín" y "Alma devota"), mientras que Fernando García Grave de Peralta ("Borrasca"), Lino Horruitiner ("Galatera anacrónica") y Wifrido Martínez Chablé ("Semblanzas") complementan, junto a los desconocidos Augusto Vega ("Pensando en ti"), Aquiles Zorda ("Campana sorda" y "Atalaya"), Max Izaguirre Borrero ("Amor tímido") y José Echemendía Gómez ("El destino") el círculo de los "perseístas" y sus estériles estéticas de una malograda intencionalidad renovadora. El propio Luis Aguiar Poveda, que solo publicó dos textos poéticos irrelevantes ("El Caudillo" y "Abnegación”), mantuvo una presencia intermitente en la ciudad santiaguera, más interesado en su diplomado en Leyes en La Habana que en capitanear la desorientada nave de los renovadores, prontamente frustrada y disuelta el 19 de junio de 1926. Hubo que esperar dos años después para que la clarinada vanguardista orientara, aunque por breve tiempo, los nuevos rumbos de la poesía santiaguera: en la edición del Diario de Cuba correspondiente al martes 5 de junio de 1928, se anunció la constitución de una controvertida asociación de jóvenes escritores locales, algunos procedentes del fenecido Per se, pero en su mayoría desconocidos, que representaría la segunda hornada progresista intelectual del momento: el emblemático "Grupo H".

A los hermanos Palacios Estrada, Lino Horruitiner, Julián Mateo, Héctor Poveda, Luis Aguiar Poveda, Rafael Esténger, Mariblanca Sabas Alomá y Ciana Valdés, se sumaron Carlos González Palacios (19021952), Alberto Santa Cruz Pacheco, Pedro Repilado (1899-1959), Luisa Beltrán, Inés Peralta Roldán, Lucas Pichardo (1903-1959), Juan Vogelfrei (1907-?), Pedro Amador Montes de Oca (1906-1933) y el polémico Juan Ramón Breá (1905-1941), sobre quien descansó todo el protagonismo de la "Página Literaria del Grupo H". Además del indispensable artículo de Mary Low publicado en Orígenes en 1956, (69-75), existen tres interesantes valoraciones sobre el impacto de los "hacheístas" en la 
cultura santiaguera del período (Barrero 223-245; Poveda Díaz 43-53 y Perdomo Correa 180-182); no obstante, estos análisis aun resultan insuficientes: se impone, con carácter urgente, el rescate y el estudio pormenorizado de toda la producción contenida en cada una de las 16 ediciones del suplemento literario, pues resulta un valioso material documental que aporta informaciones indispensables para comprender el desarrollo de la literatura santiaguera de estos años y, sobre todo, de la influencia del vanguardismo en la cultura regional.

En relación con los propósitos ideoestéticos del grupo y su desempeño en el ámbito lírico santiaguero, es necesario comentar dos aspectos medulares: 1) el interés en redireccionar la práctica escritural local, no solo en el género poético, sino también narrativo y ensayístico, hasta el momento signados por una estética considerada anacrónica y prejuiciada que impedía su evolución. En cierta medida, esta intención implicaba un acto de rebeldía contra la parálisis cultural imperante, clamaba signos visibles de apertura estética a las nuevas tendencias revolucionarias del arte, y en particular, de la literatura; 2) aun cuando una revisión detenida de los textos publicados permite constatar un nutrido registro de indiscutible calidad literaria, prevalece, no obstante, la heterogeneidad composicional en el discurso lírico "hacheísta", todavía contaminado por el tradicional romanticismo, el simbolismo decadentista y el desgastado posmodernismo al estilo povedeano.

Estos rezagos formales y conceptuales atentaron contra la sedimentación de la influencia vanguardista que, una vez más, fue infructuosamente asimilada y comprendida en su totalidad por los miembros del grupo. Luis Poveda, por ejemplo, no consiguió exorcizar el fantasma de Versos precursores en textos que preconizan la amargura del sujeto lírico desesperanzado ante el presente agónico y el futuro incierto; de ahí su interés en resaltar, esencialmente, lo grotesco de la vida en "La culpa", "El pareado" y "Cuadro futuro". Su primo Héctor Poveda, en tanto, no lograría desembarazarse de una nutrida madeja simbolista que remeda la estética del decadentismo francés, en poemas de notoria factura como "Dios y yo", "El hermano en Darwin", "El cráneo de la indigencia", "Sol de hospital" y "Sol en presidio", fieles a los preceptos formales que caracterizan su recién publicado poema- 
rio Crepúsculos fantásticos. Por otra parte, Lino Horruitiner, que ya se había dado a conocer a inicios de 1920 en revistas culturales locales como Aguilera (1920) y Archipiélago (1926-1928), apuesta por el trillado equilibrio posmodernista-romántico, camino que transitarán, en igual medida, Mariblanca Sabas Alomá, Ciana Valdés Roig y Carlos Manuel González Palacios, aunque ello no significó que indistintamente hicieran uso de ciertos recursos distintivos de la renovación vanguardista, como el prosaísmo, el abandono de la tradicional puntuación y la ruptura con la formal estructura gramatical del verso, en escasas e intrascendentes composiciones.

De mayor atención, y más cercanos a esta estética, se encuentran los textos "Lluvia", "La novia", "Trazo", "Árbol seco", "Almanaque" y "Jardín", de Julián Mateo, propicios al geometrismo sutil y simbólico de la imagen poética y al tono conversacional que no esconde la predilección del hablante lírico por la personificación impresionista del detalle abstracto y superfluo del entorno citadino y la naturaleza muerta, transparentando así el aliento angustioso, la frustración y soledad del individuo. Francisco Palacios Estrada pondera temas de valor universal un tanto manidos en composiciones que visualizan, sin embargo, cierta influencia del ultraísmo europeo ("Capricho mesiánico", "Caballo de carretilla", "Jazz Band", "Símbolo" y "Type writer"), y Juan Ramón Breá ofrece una poética de especial interés, nutrida de la exégesis surrealista en "Subconsciencia", "Casa vacía", "Inventario", aunque en "La Revolución. Mi última novia", "Horizonte de obús" y "Mi Isla" muestra una acusada orientación social de militancia izquierdista. Su lirismo experimental dilucida un exquisito trasfondo de idealismo romántico, pues Breá fue, ante todo, un revolucionario radical vinculado al anarquismo político en Cuba, aunque simpatizante con la causa comunista recién fundada en la isla en 1925, durante el período de la cruenta dictadura de Gerardo Machado y Morales (1925-1933), y en España participó en la guerra civil de 1937 en el frente de Aragón y Toledo. Sus textos en las páginas del "Grupo H" y los compilados en el libro póstumo Poemas de entonces (1942), por su esposa Mary Low, también desatendido por la crítica, son quizás los más interesantes entre los publicados por los miembros de este grupo. Se trata de una poética 
que merece un análisis más detallado que escapa a los objetivos de este ensayo, debido a su validez estética en el contexto de la lírica cubana.

Por otro lado, las singulares ramificaciones de la vanguardia en la poesía, como la tendencia negrista o afrocubana, la de orientación social y la de expresión purista, requieren un detenimiento preliminar que puede servir de cartografía para los estudiosos interesados en el tema. La poesía afrocubana tiene una singular presencia en la producción lírica de estos años. La publicación en La Habana del célebre poemario de Nicolás Guillén Motivos de son en 1930, así como sus textos posteriores, contribuyeron a la implementación de la "moda afrocubana", de indiscutible esencia popular. Los poetas santiagueros no pudieron sustraerse a este tipo de práctica escritural, aun cuando las composiciones escritas posteriores al poemario guilleneano evidenciaron una estética que imitaba más que aportaba, sin lograr, en muchos casos, las resonancias estéticas que alcanzaría el Poeta Nacional de Cuba. El intelectual José Antonio Portuondo Valdor (1911-1996), entre 1932 y 1934, escribe tres poemas en los que se aprecian sus discretas incursiones en la temática del negrismo: "Rumba de la negra Pancha", "Firulítico" y "Lance de Juruminga" (Guirao 135-142). Sin embargo, el primer poemario íntegro aparece en 1937, de la autoría de Clavijo Tisseur: A ritmo de tambor, considerado por Primitivo Cordero Leyva como el "Motivos de son orientales". Para este crítico y también prologuista del libro, Clavijo Tisseur se erige como el primer poeta en cultivar la tendencia negrista en Santiago de Cuba "a la feliz y original manera de Nicolás Guillén" (26). Y a continuación agrega: "Nos consta, a sus amigos, que nadie antes que él, se consagró con tan ejemplar devoción de hermano - por la doble fraternidad social y del espíritu- a cultivar los temas negros que descubrió e impuso Nicolás Guillén" (26). Visto el texto a la luz de los estudios contemporáneos, el criterio de Cordero Leyva puede parecer pretensioso y hasta exagerado, pues en realidad $A$ ritmo de tambor lejos está de lograr el alcance y la significación estética que tuvo Motivos de son para la lírica nacional.

No obstante, vale resaltar que el poemario de Clavijo patentiza una unidad funcional desde el punto de vista ideotemático: la vida del negro esclavo y la explotación a la que fue sometido durante la etapa colonial, 
un pasado todavía no superado en la época debido a los diferentes grados y motivos de discriminación racial que sufría la población negra y mulata en Cuba. La mirada retrospectiva del hablante lírico se detiene en la exposición de los caracteres psicológicos del negro, sus rasgos físicos y conductuales, así como en sus ritos festivos tradicionales como parte de los valores y esencias de la cultura e idiosincrasia insular, en composiciones como "Amor de esclava", "Psicología de la esclava", "Filosofía del negro", en tanto que el prejuicio racial, las costumbres religiosas ancestrales asociadas a la praxis ritualística pagana y el tanatismo, el culto sagrado a sus antepasados orishas en "Liturgia del camposanto", "Jerarquía de Changó", "Responso de Margarita" y "La muerte de Taita Juan", entre otros, se perfilan como los tópicos más significativos del poemario.

Entre los cultivadores de esta tendencia poética en Santiago de Cuba posteriores al texto de Clavijo se encuentran Mary Brooks Catasús (1910-?), con Pétalos (1939), de corte neorromántico, en el que inserta los textos "En el bohío", adscrito a la temática rural, y "La negrita fina", atento a la vida marginal del negro y el mulato en el ambiente citadino, sus costumbres, fiestas carnavalescas y particularmente el retrato de la sensualidad de la mujer mulata vinculado al tema amoroso que no esconde una proyección satírica que tiende a la ridiculización del personaje lírico. Amor Pérez Rodríguez, en Vuelo de mariposas (1941), incluye "Tú ere negla... de veldad!..." (sic), de típico sabor costumbrista solariego que conjuga el choteo criollo con la característica variante de la norma lingüística popular de la región oriental de Cuba. El ya mencionado Esténger Neuling, en su libro Retorno (1945), experimenta una poesía evocadora del pasado legendario esclavista con "La leyenda del cimarrón", poema de interés por su abordaje del sincretismo religioso. Carlos Manuel González Palacios en Villa y alma (1948) hace énfasis en los aspectos de la marginalidad negrista en dos de sus poesías: "Barquillero" y "A la charagua", temas que tendrán su apogeo y epílogo en el poemario más importante de los que integran esta variante: me refiero al libro A golpes de maracas. Poemas negros en papel mulato (1950), del célebre escritor local Félix Benjamín Caignet (1892-1976), por estos años radicado en La Habana. Sus textos evocan la esencia 
de las manifestaciones de la cultura popular de Santiago de Cuba, vinculado a las tradiciones festivas de la población negra y mulata: por ejemplo, las prácticas rituales danzarias, expresiones de la música, el costumbrismo, la variante de lengua del español en la zona oriental de Cuba, las relaciones amorosas y el folclor en sentido general. Caignet privilegia el tono descriptivo con una intencionalidad bien clara: eran textos destinados a ser declamados en público en espectáculos culturales, algunos de ellos con un marcado énfasis en el choteo y la nota humorística en sus modos de caracterizar el comportamiento social de la comunidad negra santiaguera, la vida del negro y el mulato en una ciudad de heterogénea composición cultural y racial. Pueden citarse entre los de mayor relevancia de este volumen a "El bongosero", "Un piropo en la calle", "Que muera er son" (sic) en los cuales su denominador común es el tinte caricaturesco y costumbrista con la que su autor reviste a sus personajes y situaciones.

En su intención de incorporar la riqueza sonora del habla popular, entremezcla matices de un español deformado en el que prevalecen los cambios morfológicos en la versificación: el seseo, el yeísmo, omisiones consonánticas, aféresis y apócopes, además del empleo de vocablos africanos y otros neologismos carentes de sentido lógico, con los cuales dota a sus textos de musicalidad y realismo, algo muy frecuente en las composiciones de tema afrocubano (Fernández Retamar 63). No puedo dejar de señalar que las composiciones de Caignet, al ser declamadas en espectáculos públicos de diversa índole, le otorgaron un merecido prestigio popular.

Como puede apreciarse, la poesía negrista o afrocubana en la obra de escritores santiagueros tuvo un surgimiento tardío que, incluso, encontró su desarrollo más allá de los límites cronológicos conferidos por la crítica y la historiografía literaria a este tipo de expresión poética en Cuba (1930-1933). En general, se trata de una poética imitadora de estas formas populares del hecho lírico que prevaleció hasta bien entrado los años cincuenta del siglo XX.

La exégesis purista, en cambio, ha sido la de menor raigambre en los poetas santiagueros. Esta línea es perceptible en composiciones de Clavijo Tisseur incluidas en los ya citados Cantos a Elvira, Antología 
ideal y su ulterior Poemas para el alma (1958), en los cuales el sujeto lírico se refugia en la sensibilidad del arte y la naturaleza en versos que no reflejan un acabado artístico bien logrado, pero que seducen, sin embargo, por su espontaneidad y sencillez. La orientación filosófica de su poesía tiende a una espiritualidad que pretende una indagación metafísica, la fusión del hombre con la divinidad creadora, la pervivencia de la fe y la esperanza de una vida más allá de lo terrenal. El misticismo clavijiano consigue sus mejores momentos en sus poemas en prosa que lo acercan a la vertiente neorromántica.

La poesía de orientación social y proletaria, aunque ya había tenido algunas expresiones tempranas en textos de José Olano (1868?), Luis Augusto Méndez (1888-1970), Enrique Caignet (1892-1976) (Ramírez 2016: 216-217) y de Breá, mantendrá su eventual presencia en escasos poemarios posteriores a 1930, de autores como Cecilio de los Santos Sarret (1900?-?) que publica “iOh, bueyes proletarios!" en Tierra. Saretinas, La Montaña y otros poemas (1935) y "La Zafra", en Plasmas alucinantes (1947); Esténger Neuling y su texto "Corte de caña", perteneciente al mencionado libro Retorno, y en Clavijo con "La zafra ha terminado", "No hay un solo camino" y otros de su volumen Lira agreste (1948). En todos es evidente la impronta del paradigmático La zafra (1926) del matancero Agustín Acosta quien mantuvo una frecuente interacción intelectual en las actividades literarias de la ciudad santiaguera a inicios de la era republicana. Como ya es conocido por la historiografía cubana, su libro estableció pautas para el desarrollo de la estética proletaria en la lírica nacional de este lapso. Aunque las poesías indicadas de estos autores aparecieron compiladas en fecha demorada, casi todas habían sido publicadas a finales de 1920 en la "Sabatina Literaria" de El Cubano Libre o en revistas culturales del momento como Actualidades, Luz de Oriente, Archipiélago y en Revista de Oriente (1928-1931), por solo citar las de mayor impacto en el escenario local.

Más apegado a esta orientación estética clasifica el poemario Zumo (1935) de Juan Francisco Sariol, radicado por estos años en Manzanillo, donde además de ejercer una labor importante como editor propietario de la conocida revista Orto y su editorial El Arte en esa ciudad, lideró 
allí un grupo literario que nucleó a los más significativos exponentes de la avanzada intelectual del período en la región oriental del país; algunos de ellos, incluso, residentes en La Habana. Del poemario se distingue "Luces de arrabal", de efectiva denuncia social, atento a la desigualdad, la marginalidad y la pobreza extrema de la vida en provincias, sobre todo de los sectores más vulnerables de la población como los niños, los cuales representan encarnaciones simbólicas de los ideales de justicia y lucha de Máximo Gómez y José Martí, héroes de la independencia cubana. "Versos subversivos", "Hombre", "Epitafio" y "Vendrán un día hombres", también integran este volumen de aliento proletario y de proyecciones ideológicas socialistas. Tales composiciones son expresivas de la madurez política alcanzada por la intelectualidad más progresista de la región que aspiraba a redimir la República de la corruptela gubernamental, el intervencionismo norteamericano y la indiferencia colectiva ante la pérdida de los valores morales y patrióticos. Estas poesías fueron escritas en pleno período de efervescencia revolucionaria y de lucha contra la dictadura de Gerardo Machado y Morales (1925-1933), que sumió al país en el terror y el crimen políticos.

En resumen, las resonancias vanguardistas en el discurso poético de autores santiagueros de la etapa no deben entenderse como un fenómeno artístico-literario que propició una ruptura total con las formas y contenidos temáticos de la lírica anterior. El "Grupo H” y su órgano, aunque de mayor perdurabilidad que su antecesor Per se, tuvo también una vida efímera, de apenas cuatro meses, entre junio y septiembre de 1928. Sus miembros, tras la partida de Breá para La Habana, se disolvieron impulsados por sus heterogéneas inquietudes intelectuales y revolucionarias. Algunos encontraron la muerte trágica prematura (Breá y Montes de Oca, por ejemplo, cayeron combatiendo por sus ideales; Julián Mateo, enfermo, agobiado y miserable, moriría lejos de Cuba) y otros permanecieron relegados al quietismo provinciano, retirados de toda actividad cultural y literaria. El marasmo y el silencio al que se entregaban apagarían sus voces con el paso del tiempo; sus textos quedarían sumergidos durante años en el olvido. 


\section{Consolidación y decadencia del neorromanticismo}

En lo sucesivo, el discurso lírico regional transitará entre un posmodernismo resistido a desaparecer y los asomos vanguardistas, en su mayoría insustanciales y con escaso rigor creativo, que cederán paso a la consolidación de la lírica neorromántica. Aunque en este estudio no se pretende sentar pautas para una periodización definitiva del género en el contexto literario santiaguero, puede afirmarse que a partir de 1935 y hasta 1958 se percibe una etapa de escasos aportes, tanto de autores como poemarios de calidades estéticas irregulares.

El neorromanticismo, lejos de amilanarse ante las expresiones diversas e intermitentes de la vanguardia, quedó fortalecido como estética predominante en estos años. Se retoma la poesía de tema histórico, centrada, en lo fundamental, en la exaltación de las figuras patrióticas de mayor incidencia en el contexto local, cristalizando la tradición que aborda como paradigma de la idiosincrasia regional la figura del líder independentista Antonio Maceo, incluso con mayor preferencia que la del héroe nacional José Martí por su condición de prócer local. Estas composiciones aparecieron como poemas independientes, casi siempre, en publicaciones culturales del momento como Acción Ciudadana (1940-1960), Revista Oriental de Cuba (19521956), Azul (1944-1957) -dedicada al público femenino-, Orientación Social (1951-1960), Galería (1957-1960), entre otras, pues en 28 años escasamente se editaron, hasta donde se ha conseguido investigar, 22 poemarios.

En la década de los años cincuenta, la estética neorromántica constituyó un aliciente ante el agravamiento de la compleja situación política del país, y en particular de la ciudad de Santiago de Cuba, durante la sangrienta dictadura de Fulgencio Batista (1952-1958). Acontecimientos históricos de trascendental importancia como la celebración del centenario del natalicio del héroe nacional cubano en 1953 encontró reflejos notorios en el poemario Canto a Martí (1953) de Pura del Prado (1931-1996); sin embargo, las poesías escritas en este lapso sobre temas vinculados a la lucha insurreccional contra el régimen de Batista, como el asalto al Cuartel Moncada el 26 de julio de 1953, el alzamiento de Santiago de Cuba en 1956, los asesinatos 
de los hermanos País García en 1957, la guerra de guerrillas en la Sierra Maestra entre 1956 a 1958, etcétera, por motivos de evidente censura y represión políticas, permanecieron inéditas hasta el triunfo de la revolución protagonizada por Fidel Castro. En este sentido se indican los textos "Canto a Fidel Castro" y "Elegía a Frank País" de Pura del Prado (Sarabia 197-205) y "A mi hermano", del legendario líder insurreccional santiaguero Frank País, inspirado en el asesinato de su hermano Josué por los esbirros de la dictadura (Ramírez 96-103). A lo anterior se añade que escasos escritores integrantes de nuevos espacios literarios en la vida cultural de la ciudad, como el Círculo Artístico-Literario "José María Heredia” y el Grupo Galería, por ejemplo, colaboraron activamente o en cierta medida con la insurgencia revolucionaria en la clandestinidad, y se vieron imposibilitados de publicar sus obras antes de 1959.

Aquellos que prefirieron mantener una postura apolítica en la divulgación de su quehacer escritural estuvieron insertados en el ámbito publicitario, político y cultural de la ciudad o bien alejados de esta, como Cecilio de los Santos Sarret, pedagogo, matemático, poeta y ensayista, cuyas primeras incursiones en el género lírico ven la luz en El Cubano Libre entre 1919-1921 y también en Actualidades. En los ya mencionados Tierra... y Plasmas alucinantes, las poesías de Sarret -sus "saretinas" o "sarretinas" como prefiere llamarle (un neologismo que alude a su apellido)- constituyen un conjunto de décimas paisajísticas que evocan el entorno rural de su infancia. En estas composiciones, de rezagado posmodernismo y tenues pinceladas vanguardistas, apuestan por la liberación espiritual del sujeto lírico y siguen, por lo regular, el sentido reflexivo del intimismo filosófico que advierte la preocupación autoral por los conflictos existenciales de la condición humana.

Las Poesías (1939) de Manolo Sabater Camps (1902-?); Cambula. Canto a Heredia y otros poemas (1940) de Renée Pérez Rizzo (19021980?) y los Solipleniums de Casto Jesús Fabrá, todos de menores relieves artísticos, entrecruzan registros de trillada tesitura neorromántica $\mathrm{y}$, en ella, la poesía de evocación patriótica. Los ya señalados Villa y alma de González Palacios y Poemas negros en papel mulato de Caignet comparten nuevas connotaciones semánticas que revitalizan la relación 
conceptual entre poesía-identidad-cultura en el discurso lírico de los autores santiagueros. Clavijo Tisseur, ya en el ocaso de su producción poética, editará El libro de mi hija muerta (1941), poesía intimista, de valor autobiográfico y muy poco lograda desde el punto de vista estético, a pesar de su intensa carga emotiva, y también Lira agreste (1948), poemario que transparenta el desencanto autoral ante el mundo. El yo poético prefiere el ostracismo rural, su refugio en una naturaleza agreste y descarnada, en poemas como "Dejando atrás el fardo", "Ya estoy entre el follaje" y "Una visión extraña"; en ellos prevalece una mirada desgarradora del entorno, expresiva, en síntesis, de una poética del desaliento y la decepción debido a desgarradoras experiencias personales. Poemas para el alma (1954), el último de los textos poéticos de Clavijo, pues fallecería en 1958, circunscribe la prosa reflexiva neorromántica, mística, pausada, de discretos logros estéticos aunque el libro, no obstante, acentuó su fama de poeta popular en la ciudad.

Las voces femeninas de estos años, Ciana Valdés Roig, Mary Brooks, Amor Pérez Rodríguez, Amparo Furet, Gloria Castañeda Pastor (19041995), Dora Varona (1932-?) y la ya nombrada Pura del Prado, tendrán un protagonismo singular en el fortalecimiento del neorromanticismo poético en Santiago de Cuba. De ellas solo merecen justiprecio: Cantos de cuna (1936), de Valdés Roig, un conjunto de poemas en verso y prosa de profundo sentido maternal y amoroso-intimista, y Rendija al alma (1952) de Dora Varona, escrito en la etapa de su adolescencia. Este volumen anuncia la presencia de una poetisa en ciernes que lamentablemente vio trunca su carrera lírica en los años posteriores. La obra inicial de Pura del Prado la consolida como la más interesante poetisa local de estos años. Son de su autoría De codo en el arcoiris y Los sábados y Juan, ambos de 1952. Al lirismo espontáneo, la sensibilidad desenfadada y el tono reflexivo intimista de sus versos, tal vez con matices autobiográficos, se añade un hálito surrealista que se mezcla con el lamento del hablante lírico que no permanece indiferente ante el agravamiento de la crisis política nacional. En 1956, otro de sus poemarios, El río con sed, continúa la vertiente neorromántica pero, a diferencia de los anteriores, representa el inicio de una poética que se encamina hacia la madurez conceptual que su autora alcanzará en los 
títulos publicados después de 1959, durante su etapa en el exilio en los Estados Unidos. ${ }^{5}$

La dimensión humanista en la poesía de Lino Horruitiner Caldas se hará latente en su volumen Presencia (1955), de aliento nostálgico y crepuscular acento posmodernista, muy cercano a la estética dariana. Patentada con el sello editorial Manigua, Presencia recibió positivos elogios de la crítica en las voces de José Antonio Portuondo y Ángel Augier. El autor apela a la tradición poética de arraigo popular en el abordaje de temas universales como la frustración amorosa, el erotismo refinado, los conflictos existenciales del sujeto lírico que traslucen su estremecimiento ante el temor a la soledad y la muerte, con matices cercanos al desaliento lírico y la ironía sentimental con tonos coloquiales en determinadas composiciones. El autor no esconde la influencia de la poesía española de autores como Juan Ramón Jiménez, Antonio Machado y Federico García Lorca, y su preferencia por una espiritualidad que consigue una sensibilidad lírica depurada, incluso en otros textos escritos en 1958, pero que aparecerán publicados un año después en un volumen ulterior, Clausura de la rosa, como parte de una nueva orientación conceptual en el proceso evolutivo de su obra. A pesar de los esfuerzos por revitalizar los aportes de su obra al hecho lírico nacional (Horruitiner 2002), y en particular a la literatura santiaguera del período, todavía no ha sido estudiada en detalle y gran parte de ella aún permanece inédita.

\section{Conclusiones}

La poesía santiaguera en el período de 1923 a 1958, tanto en el plano temático como conceptual, experimenta un profundo proceso de desarrollo, transformación y acoplamiento a la práctica escritural en el género que no se aparta, con mucho, de las estéticas conformadoras del discurso lírico a escala nacional.

Los autores perfilaron, en líneas generales, un proceso creativo que asimiló las tendencias predominantes. El continuum estético tuvo su

\footnotetext{
${ }^{5}$ En 1957, Pura del Prado, según indica el investigador León Estrada (2013, 212), publica un cuarto poemario titulado Canto a Santiago y otros poemas con el que cierra su producción lírica en la etapa anterior al triunfo de la revolución cubana. Hasta el momento de redactar este ensayo, no ha sido posible localizar dicho volumen en los principales archivos bibliotecarios del país.
} 
anclaje, primeramente, en un tardío posmodernismo que entró en su fase de decadencia a finales de la década de los años veinte. El influjo de las vanguardias encontró una discreta representación en los grupos literarios Per se y H; ambos de vida efímera y con discretas resonancias en el desarrollo de la literatura local y de la poesía, en particular. El proceso renovador, sin embargo, no impidió la cristalización de la vertiente neorromántica que perduró hasta 1958 en la mayoría de las publicaciones poéticas de estos años.

Se trata, en síntesis, de un quehacer lírico en gran medida abundante, en alguna medida con registros estéticos significativos para la cultura y la literatura regional; otros, con aportes discretos que no desmerecen la atención y el estudio de sus tendencias, obras y autores más importantes. El constructo estético responde al contexto sociopolítico imperante en la ciudad de Santiago de Cuba a lo largo de cinco décadas de frustración político-social, alienación, pesimismo e inconformidad con el proyecto de nación incompleta que la entrada del país a la modernidad con el advenimiento de la era republicana el 20 de mayo de 1902, agravado por las complejas coyunturas políticas que trajeron consigo las dictaduras de Gerardo Machado y Fulgencio Batista, con sus negativas consecuencias para los habitantes de la ciudad y su círculo de intelectuales en las décadas de los años treinta y cincuenta, respectivamente, del pasado siglo.

La desilusión amorosa, la exaltación de la belleza femenina, los temas histórico-patrióticos, la naturaleza como aliada inseparable de la espiritualidad del hombre y del arte en todas sus formas, los conflictos existenciales del ser humano, su desasosiego ante el entorno social, la lucha de clases, entre otros, se erigen como los principales tópicos abordados por las figuras predominantes del período. Se trata, en suma, de un espectro polisémico de variopintas inquietudes ideoestéticas que determinaron las coordenadas del hecho lírico a escala regional.

La actitud beligerante y de salvaguarda de los valores humanos, la mirada del yo poético desplazada hacia las clases desposeídas, el retrato de la existencia cotidiana, la marginalidad citadina y rural, caracterizan a la poesía de vertiente social y afrocubana. Estas composiciones resaltan la esencia de la cubanía en general y del santiaguero en particular, sus 
costumbres, expresiones religiosas y culturales, sin discriminación de credos, doctrinas y razas. En algunos casos, los autores comulgan con una praxis identitaria para con su terruño natal; sus preocupaciones, en unos de manera incisiva, en otros, de forma esporádica, establecen un discurso poético comprometido con el destino político de la nación, desde la perspectiva que distingue el peculiar contexto regional de la ciudad de Santiago de Cuba y su cultura.

\section{Referencias}

Aristigueta Sanromán, Joaquín. Huerto escondido. Poesías. Manzanillo, El Arte. 1926. Impreso.

Barrero Morell, Amparo. "El Grupo H”. Santiago 8 (1972), 223-45. Impreso.

Bisbé Alberni, Manuel. En los jardines del silencio. La Habana, Hermes. 1925. Impreso.

Breá, Juan Ramón. Poemas de entonces. Introducción de Mary Low. Habana, Casa Editora Revilla. 1942. Impreso.

Caignet Salomón y Félix Benjamín. A golpe de maracas. Poemas negros en papel mulato. La Habana, Editorial Casin, S.A. 1950. Impreso.

Clavijo Tisseur, Arturo. Poemas para el alma. Manzanillo, El Arte. 1954. Impreso.

Clavijo Tisseur, Arturo. Lira agreste. Poesía. Manzanillo, El Arte. 1948. Impreso.

Clavijo Tisseur, Arturo. El libro de mi hija muerta. Manzanillo, El Arte. 1945. Impreso.

Clavijo Tisseur, Arturo. A ritmo de tambor. Santiago de Cuba, Ros. 1937. Impreso.

Clavijo Tisseur, Arturo. Antología ideal. Poesías. Madrid, Palomeque. 1928. Impreso.

Clavijo Tisseur, Arturo. Cantos a Elvira. Poesías. Santiago de Cuba, Arroyo. 1925. Impreso.

Cordero Leyva, Primitivo. "Motivos de son orientales". A ritmo de tambor. Santiago de Cuba, Ros. 1937. 5-26. Impreso.

Duany Méndez, Pedro. Hipocrene. Versos emotivos. Santiago de Cuba: Arroyo Hermanos. 1926. Impreso.

Esténger Neuling, Rafael. Retorno. La Habana, Talleres Tipográficos. 1945. Impreso.

Esténger Neuling, Rafael. Los énfasis antiguos. Manzanillo, El Arte. 1924. Impreso. 
Estrada, León. Santiago literario. Santiago de Cuba, Oriente/ Fundación Caguayo. 2013. Impreso.

Fernández Retamar, Roberto. La poesía contemporánea en Cuba (1927-1953).

La Habana, Letras Cubanas. 2009. Impreso.

García y Grave de Peralta, Fernando: Canto a la raza. Santiago de Cuba, Arroyo Hermanos. 1928. Impreso.

González Palacio, Carlos Manuel. Villa y Alma. La Habana, Minerva. 1946. Impreso.

Horruitiner, Gladys. Lino Horruitiner: nostalgias, fulgor y sueños. Santiago de Cuba, Santiago. 2002. Impreso.

Horruitiner Caldas, Lino. Clausura de la rosa. Santiago de Cuba, Santiago. 2004. Impreso.

Instituto de Literatura y Lingüística y Ministerio de Ciencia, Tecnología y Medio Ambiente. Diccionario de Literatura Cubana, 2 t. La Habana, Letras Cubanas. 1980-1984. Impreso.

Instituto de Literatura y Lingüística y Ministerio de Ciencia, Tecnología y Medio Ambiente. Historia de la Literatura Cubana. Tomo 2. La literatura cubana entre 1899 y 1958. La República. La Habana, Letras Cubanas. 2003. Impreso.

López Lemus, Virgilio. El siglo entero. Santiago de Cuba, Oriente. 2010. Impreso.

Low, Mary. "El grupo H”. Orígenes XIII, 40 (1956): 69-75. Impreso.

Méndez, Luis Augusto: Trémulos y pétalos. La Habana, Hermes. 1926. Impreso.

Perdomo Correa, Omar. "El Grupo H: algo más que una fórmula sanguínea". Santiago Literario, Santiago de Cuba, Oriente/ Fundación Caguayo, 2013. 180-82. Impreso.

Pérez Rizzo, René. Cambula, Canto a Heredia y otros poemas. Santiago de Cuba, s.e. 1940. Impreso.

Pérez Rodríguez, Amor. Vuelo de mariposas. Versos libres. Poemas y cuentos literarios. Santiago de Cuba, Ros. 1941. Impreso.

Poveda Díaz, Alcibiades. "Esplendor a la sombra (Una noticia de la historia de Santiago)". Del Caribe, 56 (2012): 43-53. Impreso.

Poveda Sánchez, Héctor. Crepúsculos fantásticos. Manzanillo, Biblioteca Martí. 1927. Impreso.

Prado, Pura del. De codo en el arcoíris. La Habana, Pérez Sierra. 1952. Impreso. Prado, Pura del. Los sábados y Juan. La Habana, Pérez Sierra. 1952. Impreso. Prado, Pura del. Canto a Martí en 1953. La Habana, Sagitario. 1953. Impreso. Prado, Pura del. El río con sed. La Habana, Organización Nacional de Bibliotecas Ambulantes y Populares. 1956. Impreso. 
Ramírez Castellanos, Ronald Antonio. "La lírica santiaguera en la etapa republicana (1902-1923)". Revista Chilena de Literatura 92 (2016): 216220. Impreso.

Ramírez Castellanos, Ronald Antonio. "Frank País, poeta". Santiago Especial (2014): 96-103. Web. Agosto 2018.

Sabater Camps, Manolo. Poesía. Santiago de Cuba: s.e. 1939. Impreso.

Santos Sarret, Cecilio de los. Plasmas alucinantes. La Habana, Molina y Compañía. 1947. Impreso.

Santos Sarret, Cecilio de los. Tierra (Saretinas, La montaña y otros poemas). La Habana, s. e. 1935. Impreso.

Sarabia, Nydia. Pura del Prado: una voz de océano. Santiago de Cuba, Caserón. 2011. Impreso.

Siré Valenciano, Manuel. Del plantel al mesón, semblanzas líricas. Figuras del plantel. Entre escudillas. Figuras del mesón. La Habana, Hermes. 1926. Impreso.

Valdés Roig, Ciana. Cantos de cuna. Manzanillo, El Arte. 1936. Impreso.

Varona Gil, Dora: Rendija al alma. La Habana, Pérez Sierra y Hermano. 1952. Impreso.

Villaespesa, Francisco. "Prólogo". Cantos a Elvira. Santiago de Cuba, Arroyo. 1925. 10-13. Impreso. 